УДК 005.4:001.85

DOI 10.33082/2226-1893-2019-3-171-190

\title{
РОЗРОБКА ІМІТАЦЙНОӦ МОДЕЛІ УТВОРЮВАНОЇ ЦІННОСТІ НА ЛАНЦЮЗІ МАРКОВА ДЛЯ ФОРСАЙТ МЕТОДОЛОГІї
}

\author{
Лд.С. Чернова \\ к.т.н., доцент кафедри Інформаційних управляючих систем та технологій \\ Національний університет кораблебудування ім. адмірала Макарова, \\ м. Миколаӥв, Украӥна \\ Д.В. Лук'янов \\ к.т.н. кафедри Загальної та клінічної психології \\ Білоруський державний університет \\ В.Д. Гогунський \\ д.т.н., професор кафедри Управління системами безпеки життєдіяльності \\ Одеський національний політехнічний університет, Одеса, Україна \\ Лб.С. Чернова \\ к.т.н., доцент кафедри Програмного забезпечення автоматизованих систем \\ Національний університет кораблебудування ім. адмірала Макарова, \\ м. Миколаӥв, Украӥна
}

Анотація. Дослідження спирається на гіпотезу, щзо життєвий цуикл переваг проектів може бути відображений за допомогою ланцюгів Маркова. Під станами ланцюгів Маркова розуміються характерні етапи життєвого ичиклу переваг проекту. Отримані результати не суперечать прийнятій гіпотезі. Показано, щзо трансформація життєвого ичиклу переваг проектів у ланцюг Маркова є ефективним способом для феноменологічного відображенням проектної структури, щуо базується на цүиклі переваг проектів. Доведено, щуо застосування ланцюгів Маркова є прий-нятним для відображення життєвого цииклу переваг проектів. Результати дослідження можуть слугувати основою для створення моделей Форсайт-проектів.

Ключові слова: форсайт-методологія, життєвий изикл, імітаційна модель, ланц̧юг Маркова, ичінність.

() Чернова Лд.С., Лук'янов Д.В., Гогунський В.Д., Чернова Лб.С., 2019 
УДК 005.4:001.85

DOI 10.33082/2226-1893-2019-3-171-190

\title{
РАЗРАБОТКА ИМИТАЦИОННОЙ МОДЕЛИ СОЗДАВАЕМОЙ ЦЕННОСТИ НА ЦЕПИ МАРКОВА ДЛЯ ФОРСАЙТ МЕТОДОЛОГИИ
}

\author{
Лд. С. Чернова \\ к.т.н., доцент кафедры Информационных управляющих систем и технологий \\ Национальный университет кораблестроения им. адмирала Макарова, \\ м. Миколаїв, Украӥна
}

Д.В. Лукьянов

к.т.н. кафедры Общей и клинической психологии

Белорусский государственный университет

В.Д. Гогунский

д.т.н., профессор кафедры Управления системами безопасности жизнедеятельности

Одесский наџиональный политехнический університет, Одесса, Украина

\section{Лб. С. Чернова}

к.т.н., доцент кафедры Програмного обеспечения автоматизированных систем

Национальный университет кораблестроения им. адмирала Макарова,

$$
\text { м. Миколаїв, Україна }
$$

Аннотация. Исследование опирается на гипотезу, что жизненный ичикл преимущуеств проектов может быть отображен с помощьью цеепей Маркова. Под состояниями цепей Маркова понимаются характерныл этапь жизненного цикла преимуществ проекта. Полученные результаты не противоречат принятой гипотезе. Показано, что трансформация жсизненного циикла преимуществ проектов в цчепь Маркова является эффективным способом для феноменологического отражения проектной структуры, основанной на цикле преимуществ проектов. Доказано, что применение чепей Маркова является приемлемым для отображения жизненного ичкла преимуществ проектов. Результать исследования могут служить основой для создания моделей Форсайтпроектов.

Ключевые слова: форсайт-методология, жизненный циклл, имитационная модель, цчепь Маркова, цченность. 
UDC 005.4:001.85

DOI 10.33082/2226-1893-2019-3-171-190

\title{
DEVELOPMENT OF IMITATION MODEL OF THE CREATED VALUE ON CHAIN OF MARKOV FOR FORESIGHT METHODOLOGY
}

\author{
Ld.S. Chernova \\ Ph.D., Associate Professor \\ Department of Information Management Systems and Technologies \\ Nikolaev University of Shipbuilding them. Admiral Makarov, \\ Nikolaev, Ukraine \\ D.V. Lukianov \\ $\mathrm{PhD}$, Associate Professor \\ Department of General and Clinical Psychology \\ Belarusian State University \\ V.D. Gogunskii \\ Doctor of Technical Sciences, Professor \\ Department of Systems Management Life Safety \\ Odessa National Polytechnic University, Ukraine \\ Lb. Chernova \\ Ph.D., Associate Professor \\ Department of Computer-aided Systems Softare Support \\ Nikolaev University of Shipbuilding them. Admiral Makarov, \\ Nikolaev, Ukraine
}

\begin{abstract}
The study is based on the hypothesis that the life cycle of project benefits can be reflected by Markov chains. The states of Markov chains are understood as the characteristic stages of the life cycle of a project's benefits. The results obtained do not contradict the accepted hypothesis. It has been shown that the transformation of the life cycle of project benefits into a Markov chain is an effective way to phenomenologically reflect a project structure based on the project benefits cycle. It has been proven that the use of Markov chains is acceptable to reflect the life cycle of project benefits. The results of the study can serve as a basis for creating models of Forsyth projects.
\end{abstract}

Keywords: foresight methodology, life cycle, imitation model, Markov chain, value. 
Вступ. До ключових заходів, що сприяють ефективності підходу до управління цінностями, слід приступити ще до початку виконання програми розвитку. Ці дії тривають протягом всього життєвого циклу програми розвитку і навіть після ії завершення.

Найважливішим внеском у планування програми розвитку є розстановка пріоритетів серед реалізованих цінностей. Наприклад, обгрунтування цінностей на ранньому етапі може виявитися вкрай необхідним для того, щоб забезпечити подальше фінансування програми розвитку, незважаючи на більш високу вартість прискореної реалізації цінностей, ніж в разі застосування програмного підходу, що уповільнює отримання вигід. Аналогічним чином, на більш пізні етапи виконання програми розвитку можна запланувати ті види діяльності в рамках програми розвитку, які пов'язані з цінностями, що впливають на сфери роботи підприємства, або з цілями, які підлягають подальшим змінам.

Мета управління цінностями - шляхом залучення до процесу ключових зацікавлених сторін вирішити проблему ризику, пов'язаного 3 тим, що в сферах основної діяльності не буде досягнута привабливість цінностей. Це, в свою чергу, зменшує ймовірність прогнозування нездійсненних цінностей на етапі формування програми розвитку виключно 3 прагнення до отримання інвестицій. Крім того, управління цінностями дає можливість планування та перепланування програм або навіть відмови від таких програм, які, очевидно, не принесуть достатніх цінностей. У міру того як проекти і програми розвитку стають все більш важливим елементом діяльності підприємства, управління цінностями сприяє створенню організації, здатної до навчання, і допомагає створювати базу знань про характеристики програм, що приносять стабільні цінності для підприємства.

У такому разі завдання управління полягає в розробці, яка дозволяє розв'язувати завдання досягнення поставлених цілей в умовах обмеженості часових, фінансових, матеріальних, людських та інших видів ресурсів.

Аналіз основних досліджень і публікацій. У Форсайт-проектах за визначенням виникають протиріччя взаємодії між елементами проектної системи, які обумовлені наявністю множини невизначенностей зовнішніх та внутрішніх факторів [1]. Невизначеність зовнішнього середовища у сукупності з унікальністю завдань, які розв'язує Форсайт-проект, у разі відсутності проектів аналогів, визначають необхідність дослідження таких систем не за елементами, а на основі системного підходу [2].

За системним підходом можна виявити емерджентні властивості проектних систем - певні характеристики, які не властиві окремим елементам, а також сумі властивостей елементів [18]. Означені емерджентні властивості спрямовують дослідження процесів у Форсайт-проектах (проектних системах) не за властивостями окремих складових, а для проекту в цілому [19]. Для опису траєкторій розвитку Форсайт-проектів у коорди- 
натах ймовірностей станів елементів системи пропонується використовувати феноменологічні моделі [13]. Один з таких підходів пов'язаний 3 класом моделей, які відображаються ланцюгами Маркова, що орієнтовані на відображення залежностей між вхідними і вихідними параметрами без урахування фізичної сутності процесів. У той же час ланцюги Маркова враховують топологічну структуру зв'язків між елементами системи. «Настроювання» та ідентифікація параметрів моделей на певні системи може здійснюватися завдяки визначенню умовних ймовірностей переходів між елементами системи [11].

3 використанням ланцюгів Маркова досліджені властивості управління проектами при розв'язанні завдання ініціації проектів з охорони праці [10]. Особливості відображення проектів «навчання упродовж життя» показані через властивості ланцюгів Маркова [11]. У роботі [8] марківська модель відображає проект підготовки спортсменів до змагань. Для відображення комунікацій в проектній команді також використаний ланцюг Маркова [12]. Побудова вказаних моделей виконувалось завдяки декомпозиції об'єктів на дискретні стани з урахуванням переходів між елементами системи за допомогою орієнтованого графу [12]. Складність ідентифікації вказаних моделей пов'язана з різними способами задання умовних ймовірностей переходів. Тобто специфіка відображення різних об'єктів однорідними ланцюгами Маркова $з$ дискретними станами і дискретним часом визначається способами обчислення перехідних ймовірностей [9].

Моделі спрямовані на розв'язання завдань досягнення поставлених цілей в умовах обмеженості часових, фінансових, матеріальних, людських та інших видів ресурсів. Тому $є$ актуальним розробка методу трансформації відомих зображень структур проектів у графічній формі у ланцюги Маркова, які дозволяють моделювати суттєві характеристики проектів, щоб і здійснити перехід від якісних до кількісних оцінок траєкторій розвитку проектів [3]. Комунікативні зв'язки між елементами проектів є суттєвішою умовою успішної реалізації проектів [4], яка часто $\epsilon$ характеристикою рівня технологічної зрілості організацій, що залежить від компетентності і майстерності виконавців проекту [5].

Мета і завдання дослідження. Метою дослідження є розробка моделі життєвого циклу переваг проекту з використанням марківського ланцюга. Для досягнення поставленої мети були означені наступні задачі:

- розробити метод трансформації когнітивної схеми життєвого циклу переваг проектів в ланцюг Маркова;

- виконати формалізацію визначення перехідних ймовірностей марківської моделі з урахуванням витрат часу на здійснення комунікацій між елементами системи;

- дослідити особливості практичного визначення траєкторії розвитку життєвого циклу переваг проектів в умовах різних характеристик технологічної зрілості системи. 
Викладення основного матеріалу. Відобразимо структуру когнітивної моделі життєвого циклу переваг проектів десятьма дискретними станами [6]. Для побудови ланцюга Маркова для життєвого циклу переваг проекту - як комунікацій між станами проектної системи, зазначимо основні переходи між цими станами [7]. Це дозволяє відобразити загальну схему зв'язків між станами системи. Ці зв'язки фак-тично відображають переходи між станами системи у разі представлення іï орієнтованим графом на рис. 2.

В ланцюгах Маркова сума ймовірностей всіх станів дорівнює одиниці [8]. Переходи 3 кожної вершини графу є несумісними подіями тобто сума ймовірностей переходів 3 кожної вершини дорівнює одиниці [9]. 3 цими припущеннями граф трансформується у ланцюг Маркова 3 дискретними станами [3]. В орієнтованому графі покажемо зв'язки затримки в кожному 310 станів. У разі цих трансформацій отримаємо ланцюг Маркова (рис.1).

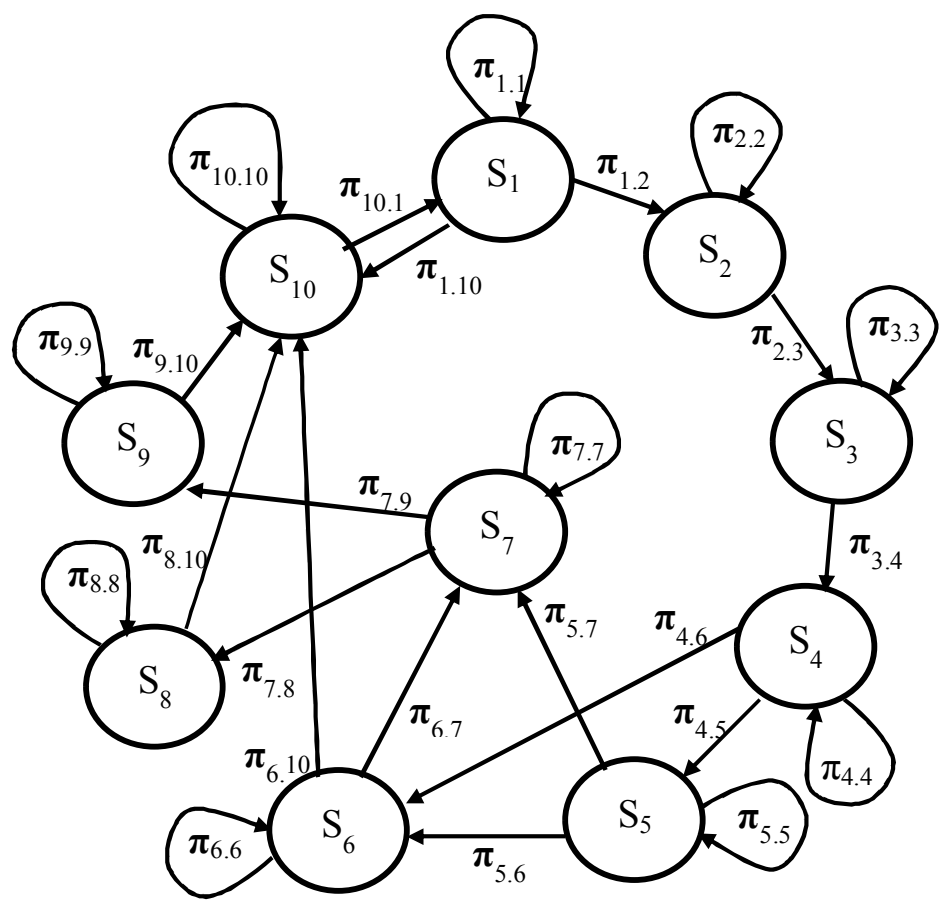

Рис. 1. Розмічений граф ланщюга Маркова,

який відображає структуру життєвого ичиклу переваг проектів: 1 -організаційні иілі; 2 -проект; 3 -продукт; 4-можливості;

5 -організаційні зміни; 6 -результат;

7 - побічні ефекти і наслідки; 8-додаткові вигоді;

9-втрати; 10 - вигоди 
Ідентифікаторами $\mathrm{S}_{\mathrm{i}},\{\mathrm{i}=1, \ldots, 10\}$ позначені вершини графу. Дана модель утворює ланцюг Маркова, оскільки, і в процесах управління проектами, і в марківських ланцюгах, існують можливі зміни ймовірностей станів системи по кроках $k$. Існують ймовірності переходів в інші стани [10]. Має місце подоба топологічної структури переходів [12].

Сума перехідних ймовірностей $\pi_{\mathrm{ij}} 3$ деякого стану $\mathrm{i} \in(1,2, \ldots, \mathrm{m})$ в інші стани $\mathrm{j} \in(1,2, \ldots, \mathrm{m})$ дорівнює одиниці [13]

$$
\sum_{j=1}^{m} \pi_{i j}=1, \quad\{i=1,2, \cdots, m\},
$$

де $\mathrm{m}=10$ - число можливих станів системи.

Загальне розв'язання системи рівнянь, які описують ланцюг Маркова, представлений на рис. 1, можна записати у матричній формі

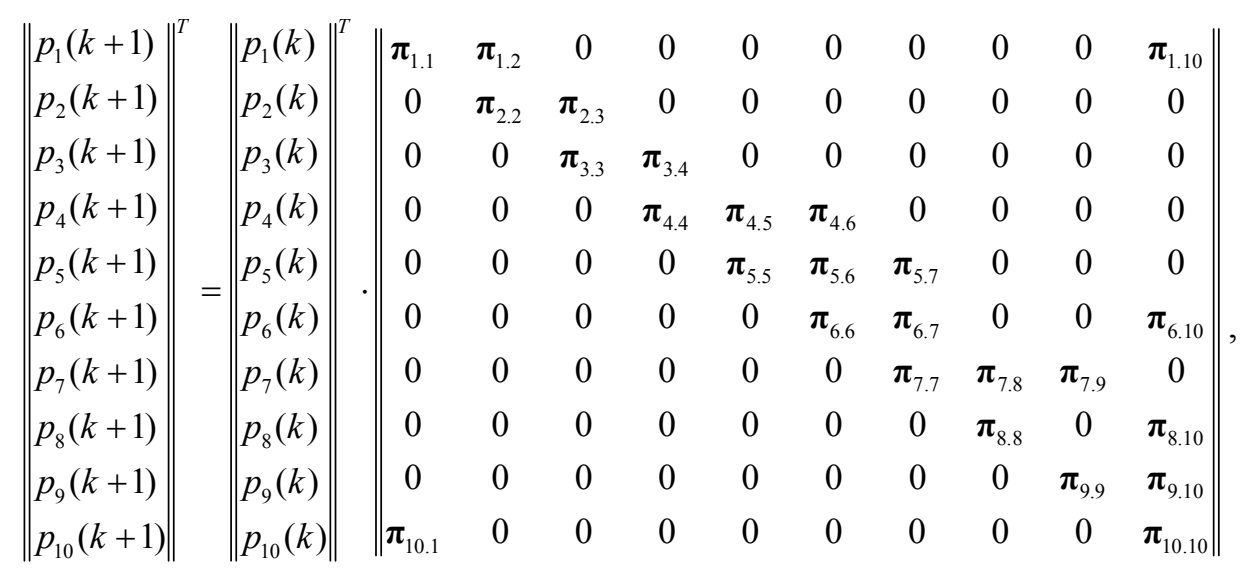

де $\mathrm{T}$ - знак транспонування стовпців;

$\boldsymbol{\pi}_{\mathrm{ij}}-$ перехідні ймовірності.

Сума ймовірностей всіх станів $\mathrm{p}_{\mathrm{i}}(\mathrm{k})$ на кожному кроці $k$ дорівнює одиниці [10]

$$
\sum_{i=1}^{m} p_{i}(k)=1
$$

де $\mathrm{p}_{\mathrm{i}}(\mathrm{k})$ - ймовірність $\mathrm{i}$-го стану на кроці $\mathrm{k}$; $i \in(1,2, \ldots, m=10)$.

За кроком $\mathrm{k}$ розуміється деякий управляючий вплив, що змінює розподіл ймовірністей $\mathrm{p}_{\mathrm{i}}(\mathrm{k})$ на наступному кроці $(\mathrm{k}+1)$ для всіх $\mathrm{i} \in(1,2, \ldots, \mathrm{m}=10)[11]$.

Якщо у (1) визначені елементи $\pi_{\mathrm{ij}}$ і відомі початкові значення $\left\{\mathrm{p}_{1}(\mathrm{k}), \mathrm{p}_{2}(\mathrm{k}), \ldots \mathrm{p}_{10}(\mathrm{k})\right\}$, то це дозволяе обчислити величини $\left\{\mathrm{p}_{1}(\mathrm{k}+1)\right.$, $\left.\mathrm{p}_{2}(\mathrm{k}+1), \ldots \mathrm{p}_{10}(\mathrm{k}+1)\right\}$ на наступному кроці $(\mathrm{k}+1)$. 
Переходи в графі у разі проектного управління відображені показані на (рис. 2). Для будь-якого дискретного стану $\mathrm{s}\{\mathrm{s} \in 1, \ldots, 10\}$ загальний час $\mathrm{T}_{\mathrm{s}}$ комунікацій 3 іншими станами можна визначити як суму тривалості часу взаємодії з цими станами $\mathrm{t}_{\mathrm{sj}}\{\mathrm{s} \in 1, \ldots, 10 ; \mathrm{j} \in 1, \ldots, 10\}[10]$

$$
T_{s}=\sum_{j=1}^{n=10} t_{s}
$$

Кожна 3 комунікацій $\mathrm{s} \rightarrow \mathrm{j}$ системи потребує певних витрат часу $\mathrm{t}_{\mathrm{sj}}$ в проекті. Значення $\pi_{\mathrm{sj}}=\mathrm{t}_{\mathrm{s} j} / \mathrm{T}_{\mathrm{s}}$ має сенс ймовірності переходу від стану $\mathrm{s} \rightarrow \mathrm{j}$.

Сума всіх перехідних ймовірностей для деякого стану s дорівнює

$$
\sum_{j=1}^{n=10} \pi_{s j}=\sum_{j=1}^{n=10} \frac{t_{s j}}{T_{s}}=\frac{1}{T_{s}} \sum_{j=1}^{n=10} t_{s j}=1 .
$$

Відтак, перехідні ймовірності $\pi_{\mathrm{sj}}$ для будь-якого зі станів $\mathrm{s}\{\mathrm{s} \in 1, \ldots, 10\}$, що представлені в кожному рядку матриці перехідних ймовірностей, утворюють несумісні групу подій. Ця властивість $\pi_{\mathrm{sj}}\{\mathrm{s} \in 1, \ldots, 10 ; \mathrm{j} \in 1, \ldots, 10\}$ дозволяє досліджувати поведінку системи при різних варіантах вхідних даних проекту. Шляхом зміни $\pi_{\mathrm{sj}}$ можна змінювати характеристики системи.

У загальному випадку перехідні ймовірності $\pi_{\mathrm{s} j}\{\mathrm{~s} \in 1, \ldots, 10 ; \mathrm{j} \in 1$, ..., 10$\}$ «налаштовують» марківські моделі на реальний об'єкт. При цьому зазвичай для визначення $\pi_{\mathrm{sj}}$ застосовуються два підходи. Перший передбачає експертне оцінювання значень перехідних ймовірностей [12]. У іншому випадку застосовується анкетування, що дозволяє визначити ймовірності станів $\mathrm{p}_{1}(\mathrm{k}), \mathrm{p}_{2}(\mathrm{k}), \ldots, \mathrm{p}_{\mathrm{n}}(\mathrm{k})$, які потім служить основою для пошуку значень перехідних ймовірностей [10]. Пропонується новий підхід, коли значення перехідних ймовірностей визначаються менеджером проекту на основі планування комунікацій в системі з урахуванням витрат ресурсів часу на виконання операцій (табл.1).

Таблищя 1

Визначення значень перехідних ймовірностей

\begin{tabular}{|l|c|}
\hline \multicolumn{1}{|c|}{$\begin{array}{c}\text { Характер комунікації } \mathrm{s} \rightarrow \mathrm{j} \\
\text { за витратами ресурсу часу }\end{array}$} & $\begin{array}{c}\text { Значення перехідних } \\
\text { ймовірностей } \pi_{s j}\end{array}$ \\
\hline Витрачається більше всього ресурсу часу & $0,8-1,0$ \\
\hline Середні витати ресурсу часу & $0,3-0,7$ \\
\hline Нижній рівень витрат часу & $0,1-0,2$ \\
\hline Незначні витрати ресурсу часу & 0,01 \\
\hline Витрати ресурсу часу відсутні & 0 \\
\hline
\end{tabular}


Зазначені в табл. 1 правила визначення значень перехідних ймовірностей дозволяють знайти дані для моделювання змін ймовірностей станів системи для проектів за будь-яких поєднаннях ресурсного забезпечення. Значення перехідних ймовірностей $\pi_{\mathrm{i} . \mathrm{j}}$ визначимо по табл. 1 . На підставі матриці перехідних ймовірностей, за умови, що початковий стан системи відомий, можна знайти все ймовірності станів системи $p_{1}(k)$, $p_{2}(k), \ldots, p_{10}(k)$ після будь-якого $k-20$ кроку за залежністю (1).

Отже, для «настроювання» марківського ланцюга 3 дискретними станами і часом на відображення властивостей конкретних систем, слід визначити всі елементи $\pi_{i j}$ у матриці перехідних ймовірностей між різними станами [13].

3 урахуванням даних табл. 1 отримаємо таке рішення для прийнятої матриці перехідних ймовірностей, яка відображає базовий варіант структури життєвого циклу переваг проекту:

Елементи матриці ймовірності у (6), вибрані за даними табл. 1. На підставі (4) і (5) зазначимо, що строки матриці перехідних ймовірностей $\epsilon$ незалежними. Кожна строчка описує характеристику певного стану щодо комунікацій з іншими станами. Так, наприклад, для стану 4 - «Можливості», це означає, що комунікації з станом 5 - «Організаційні зміни» $\left(\pi_{4.5}=0,1\right)$, а також зі станом $6-$ «Результати» $\left(\pi_{4.6}=0,1\right)$ можна віднести за витратами часу до рівня на нижньому рівні. При цьому розподіл витрат часу залежить від загального рівня зрілості проектного середовища.

$$
\left\|\begin{array}{c}
p_{1}(k+1) \\
p_{2}(k+1) \\
p_{3}(k+1) \\
p_{4}(k+1) \\
p_{5}(k+1) \\
p_{6}(k+1) \\
p_{7}(k+1) \\
p_{8}(k+1) \\
p_{9}(k+1) \\
p_{10}(k+1)
\end{array}\right\|^{\mathrm{T}}\|=\| \begin{gathered}
p_{1}(k) \\
p_{2}(k) \\
p_{3}(k) \\
p_{4}(k) \\
p_{5}(k) \\
p_{6}(k) \\
p_{7}(k) \\
p_{8}(k) \\
p_{9}(k) \\
p_{10}(k)
\end{gathered}\|.\| \begin{array}{cccccccccc}
0,8 & 0,15 & 0 & 0 & 0 & 0 & 0 & 0 & 0 & 0,05 \\
0 & 0,8 & 0,2 & 0 & 0 & 0 & 0 & 0 & 0 & 0 \\
0 & 0 & 0.8 & 0,2 & 0 & 0 & 0 & 0 & 0 & 0 \\
0 & 0 & 0 & 0,8 & 0,1 & 0,1 & 0 & 0 & 0 & 0 \\
0 & 0 & 0 & 0 & 0,8 & 0,15 & 0,05 & 0 & 0 & 0 \\
0 & 0 & 0 & 0 & 0 & 0,8 & 0,1 & 0 & 0 & 0,1 \\
0 & 0 & 0 & 0 & 0 & 0 & 0,8 & 0,15 & 0,05 & 0 \\
0 & 0 & 0 & 0 & 0 & 0 & 0 & 0,8 & 0 & 0,2 \\
0 & 0 & 0 & 0 & 0 & 0 & 0 & 0 & 0.8 & 0.2 \\
0,2 & 0 & 0 & 0 & 0 & 0 & 0 & 0 & 0 & 0.8
\end{array} \| .(6)
$$

Виходячи 3 вказаних умов для базового варіанту системи визначені однакові умовні перехідні ймовірності для всіх інших $\pi_{\mathrm{ii}}=0.8$, що відповідає згідно з табл. 1 верхнім витратам ресурсу часу.

На рис. 2 наведені результати моделювання зміни станів системи для матриці перехідних ймовірностей (6), що є базовою у даному дослідженні. 
Для певного рівня технологічної зрілості проектного середовища (організації), що відповідає сукупності значень перехідних ймовірностей $\pi_{\mathrm{ii}}=0,8$, визначених за табл. 1 , можна зробити наступні висновки. Найбільші ймовірності станів після 40-го кроку набувають стани 1 «Організаційні цілі» та стан 10 - «Вигоди» (рис. 2.).

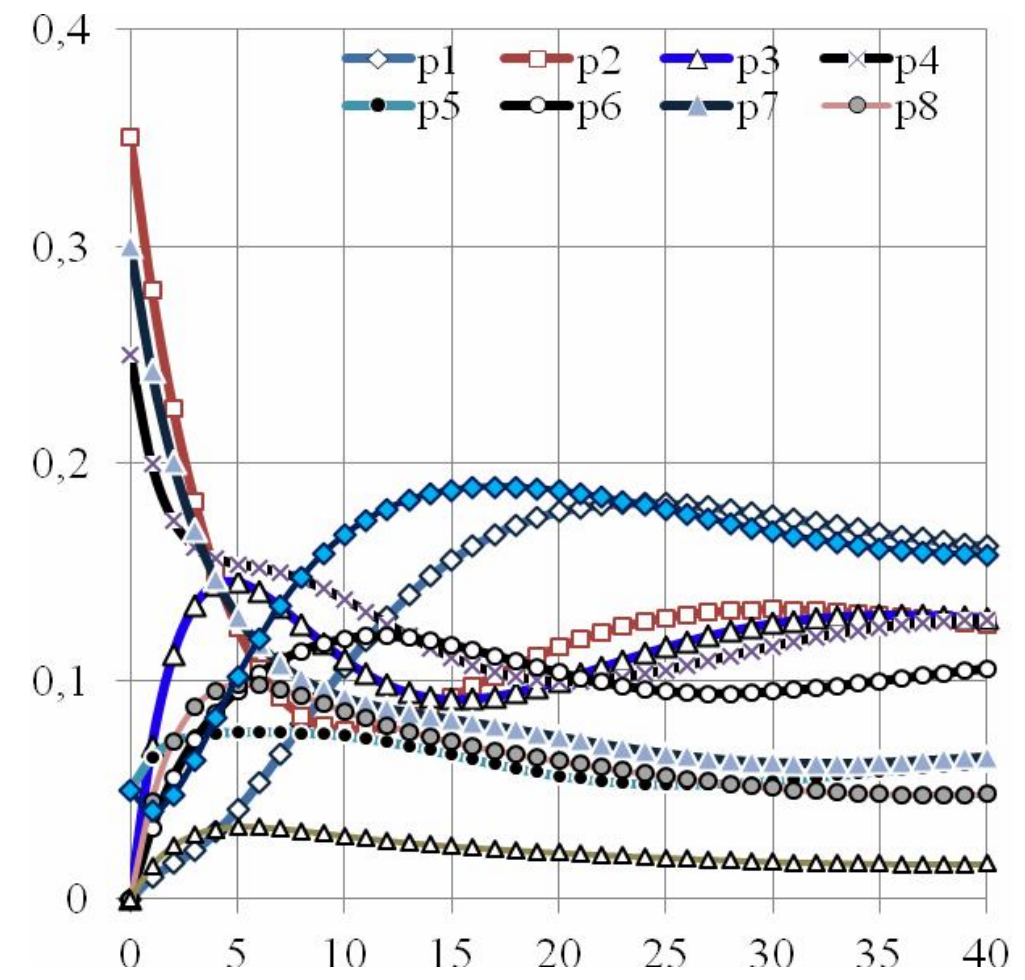

Рис. 2. Зміна ймовірностей станів системи за базовим варіантом, який відображає структуру життєвого ииклу переваг проектів $\left(\pi_{i i}=0,8 ; i=1 \ldots 10\right)$ :

1 -організаційні иілі; 2 - проект; 3 -продукт; 4 -можливості; 5 - організаційні зміни; 6 - результат; 7 - побічні ефекти і наслідки; 8 -додаткові вигодi; 9 - втрати; 10 -вигоди

Далі найбільш значущими є стани 2 - «Проект» і 3 - «Продукт», а також 4 - «Можливості». Ймовірності решти станів на 50 кроці стають значущими в інтервалі $[0 \ldots 0,1]$ - на рівні незначних витрат часу.

Для оцінки розподілу ймовірностей станів системи при інших характеристиках системи виконаємо певні зміни в матриці перехідних ймовірностей. Дослідимо вплив рівня технологічної зрілості проектного середовища (організації), що відповідає сукупності значень перехідних ймовірностей $\pi_{\mathrm{ii}}=0,3$, визначених за табл. 1. 
Такі ймовірнісні характеристики відображають стани як такі, що пов'язані з відносно малими витратами часу на особисті потреби.

Тобто, завдяки високій кваліфікації персоналу, майже весь ресурс часу використовується на роботи за проектом. Модифікація марківської моделі буде мати таке розв'язання:

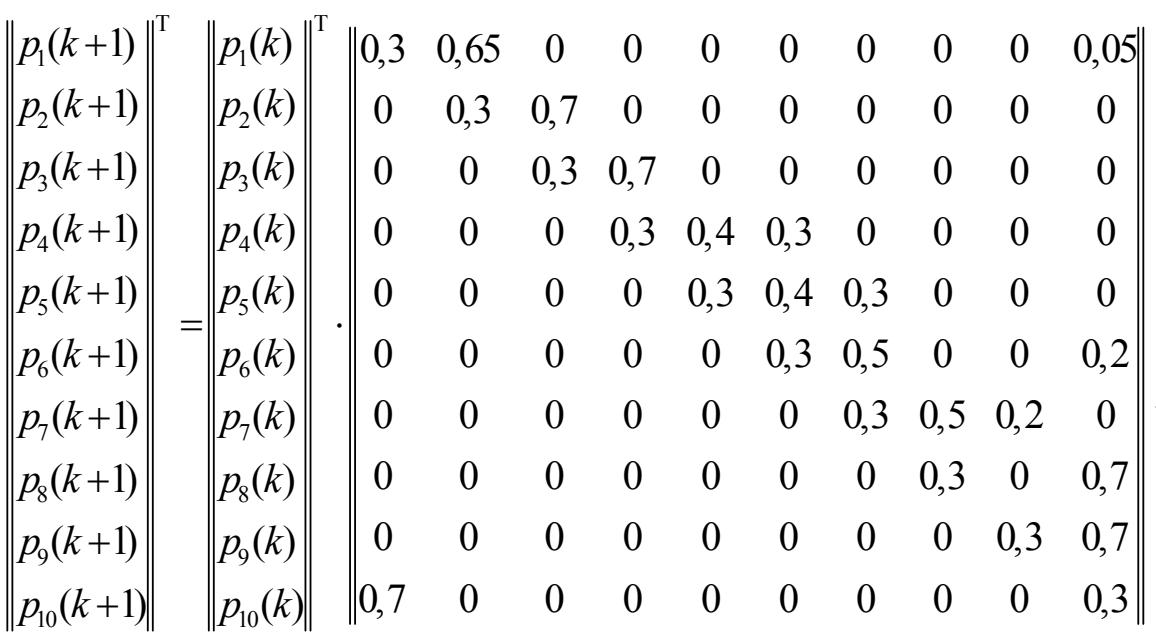
на рис. 3 .

Для цих змінених даних (7) отримаємо результати, які відображені

Для змінених умов вплив станів 1 - «Організаційні цілі», 2 - «Проект», 3 - «Продукт», 4 «Можливості», 10 - «Вигоди» життєвого циклу переваг проекту стає визначальним на 50 -му кроці у реалізації успішної проектної діяльності. При цьому характер зміни інших ймовірностей станів системи також стає відмінним від базового варіанту, що наведений на рис. 3.

В цілому, слід наголосити на тому, що така команда проекту, яка $\epsilon$ «командою зірок» $\left(\pi_{i i}=0,3 ; i=1 \ldots 10\right)$, вибудовує на початку проекту дуже складну траєкторію розвитку. I лише після 20-го кроку процес виходить на врівноважену траєкторію.

Розроблений підхід щодо трансформації життєвого циклу переваг проекту в ланцюг Маркова надає інструмент для аналізу і обгрунтування стратегії управління проектом не тільки в аспекті отримання вигод, а й дозволяє оцінити внесок кожного стану у кінцевий результат [15].

Для цього необхідно виконати ідентифікацію значень перехідних ймовірностей для кожного стану життєвого циклу будь-яким 3 прийнятних методів [17]. Це дозволить налаштувати ланцюг Маркова на відображення реальної системи для того щоб виявити «вузькі місця» в реальній проектній системі [16]. 


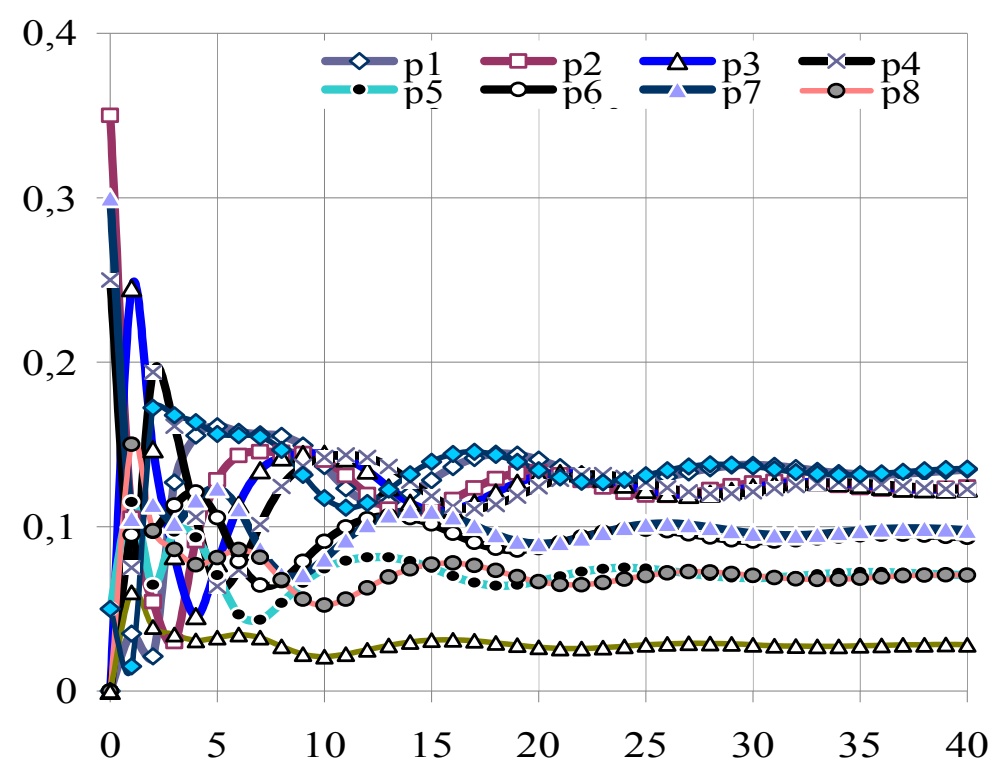

Рис. 3. Зміна ймовірностей станів системи за зміненим варіантом, який відображає структуру життєвого ииклу переваг проектів $\left(\pi_{i i}=0,3 ; i=1 \ldots 10\right)$ :

1 -організаційні цілі; 2 - проект; 3 -продукт; 4 -можливості;

5 - організачійні зміни; 6 - результат; 7 - побічні ефекти і наслідки; 8 - додаткові вигодi; 9 - втрати; 10 -вигоди

При інтерпретації даних про розвиток траєкторії проекту в координатах життєвого циклу переваг проекту за різних умов слід врахувати, що ймовірності станів системи $\left\{\mathrm{p}_{1}(\mathrm{k}), \mathrm{p}_{2}(\mathrm{k}), \ldots, \mathrm{p}_{10}(\mathrm{k})\right\}$ відображають ймо-вірності несумісних подій з повної групи. Для всіх станів $\mathrm{s}\{\mathrm{s} \in 1, \ldots, 10\}$ загальний час $\Theta$ виконання проекту на кожному кроці $\mathrm{k} є$ сумою тривалостей комунікацій в цих станах $\tau_{\mathrm{s}}(\mathrm{k})\{\mathrm{s} \in 1, \ldots, 10\}$

$$
\Theta=\sum_{s=1}^{n=10} \tau_{s}(k)
$$

де

$\Theta$ - загальна тривалість проекту;

$\tau_{\mathrm{s}}(\mathrm{k})$ - час перебування проекту в стані $\mathrm{s}\{\mathrm{s} \in 1, \ldots, 10\}$ на кроці $\mathrm{k}$.

У кожному з станів $\mathrm{s}\{\mathrm{s} \in 1, \ldots, 10\}$ на кроці $\mathrm{k}$ система може перебувати якийсь певний час $\tau_{\mathrm{s}}(\mathrm{k})$. Значення $\mathrm{p}_{\mathrm{s}}(\mathrm{k})=\tau_{\mathrm{s}}(\mathrm{k}) / \Theta$ має сенс ймовірності перебування проекту в стані $\mathrm{s}\{\mathrm{s} \in 1, \ldots, 10\}$ на кроці $\mathrm{k}$. одиниці

Сума всіх ймовірностей станів у відповідності до (3) дорівнює 


$$
\sum_{s=1}^{n=10} p_{s}(k)=\sum_{j=1}^{n=10} \frac{\tau_{s}(k)}{\Theta}=\frac{1}{\Theta} \sum_{j=1}^{n=10} \tau_{s}(k)=1
$$

Оскільки, зазначені ймовірностей станів $p_{s}(k), s\{s \in 1, \ldots, 10\}$ визначаються за (3), то з урахуванням (8) і (9) вони утворюють несумісну групу подій. Це дозволяє співвідносити величини $\mathrm{p}_{\mathrm{s}}(\mathrm{k}) 3$ тривалістю виконання робіт проекту.

Так, тривалість роботи у стані 6 - «Результат» в базовому проекті монотонно змінюється до величини $p_{6}(k)=0,106$ на кроці $k=50$ (рис. 3). Це еквівалентно 10,6 \% загальних витрат часу для базового варіанту проекту. При цьому найбільша ймовірність на 50-му кроці співвідноситься 3 станом 1 («Організаційні цілі) - 16,2 \% загальних витрат часу на проект. Стани 10 («Вигоди) - потребує 15,8 \% часу, відведеного на проект. Загальна картина відмінностей результатів моделювання базової (варіант 1) і зміненої (варіант 2) марківської моделі з вибіркою ймовірностей станів $p_{s}(k)\{s \in 1, \ldots, 10 ; k=50\}$, наведена на рис. 4.

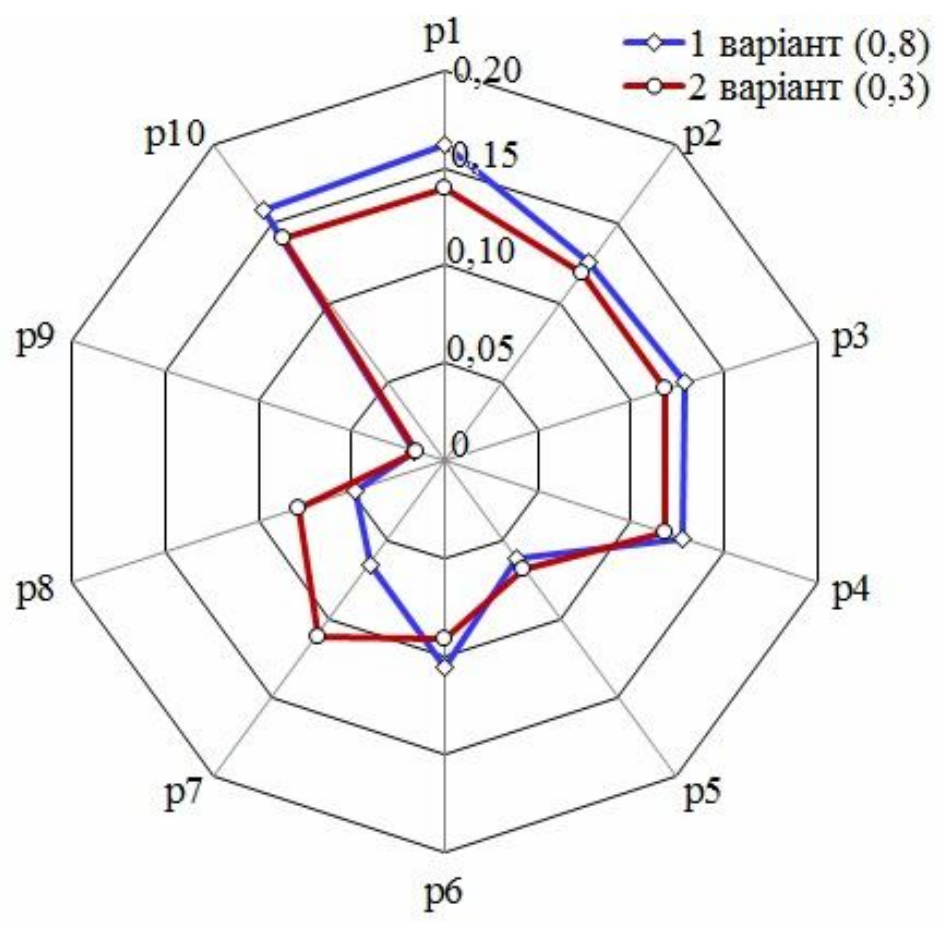

Рис. 4. Вплив рівня технологічної зрілості проектної системи на ймовірності станів системи на 50-му кроияі

Результати моделювання показують, що зміна рівня технологічної зрілості $з$ відображенням варіацій у матриці перехідних ймовірностей 
приводить до зміни загальної картини розподілу ймовірностей станів системи. У варіанті 2 моделі прийняті для всіх станів системи $\mathrm{\tau} \pi_{\mathrm{ij}}=0,3 \quad\{\mathrm{i}=\mathrm{j} ; \quad i \in 1, \ldots, \quad 10 ; j \in 1, \ldots, \quad 10\}$ на відміну від значень $\pi_{i j}=0,8\{i=j ; i \in 1, \ldots, 10 ; j \in 1, \ldots, 10\}$. За таких вхідних даних отримано результати, що відрізняються від базового варіанту 1. Результати імітаційного експерименту на розробленій моделі відображають суттєву властивість проектного управління, що результативність проектів залежить від характеристик життєвого циклу переваг проекту (рис. 4).

Теоретична частина дослідження спирається на гіпотезу, що життєвий цикл переваг проектів може бути відображений за допомогою ланцюгів Маркова. Під станами ланцюгів Маркова розуміються характерні етапи життєвого циклу переваг проекту. Отримані результати не суперечать прийнятій гіпотезі. Показано, що трансформація життєвого цикл переваг проектів у ланцюг Маркова є ефективним способом для феноменологічного відображенням проектної структури, що базується на циклі переваг проектів. Доведено, що застосування ланцюгів Маркова $\epsilon$ прийнятним для відображення життєвого циклу переваг проектів.

Запропонована трансформація життєвого циклу переваг проектів в ланцюг Маркова дозволяє перейти від якісних оцінок ходу проектів до кількісних характеристик траєкторії системи в координатах ймовірностей станів $\left\{p_{1}(k), p_{2}(k), \ldots, p_{10}(k)\right\}$ і кроків $k$. При цьому кількісні оцінки $\left\{p_{1}(k), p_{2}(k), \ldots, p_{10}(k)\right\}$ складають багатовекторну картину зміни ймовірностей станів системи по кроках [7].

Висновки. Виконано дослідження, яке проводилися в якості теоретичної основи для обгрунтування методу трансформації життєвого циклу переваг проектів в ланцюг Маркова. Створена когнітивна схема взаємодії станів життєвого циклу переваг проектів. Доведено, що декомпозиція проектної системи на стани, що утворюють цикл переваг проекту, формує систему комунікацій в проекті. Ці внутрішні комунікації визначають топологічну структуру життєвого циклу переваг проекту у формі орієнтованого графа.

Розроблено метод трансформації життєвого циклу переваг проектів в ланцюг Маркова. Це дозволяє перейти до розробки методу аналітичного покрокового розв'язання системи рівнянь ланцюга Маркова. Важливим етапом $\epsilon$ встановлення методу визначення перехідних ймовірностей. На завершення виконується «настроювання» ланцюга Маркова на відображення властивостей конкретного об'єкта для виконання досліджень за розробленою моделлю.

Показано, що ключовим процесом, який дозволяє перейти від графічного відображення життєвого циклу переваг проектів до ланцюгів Маркова, $є$ визначення перехідних ймовірностей.

Надані практичні рекомендації щодо визначення значень перехідних ймовірностей для різних станів системи. Показано, що перехідні 
ймовірності станів системи можна визначити на основі оцінок витрат часу для конкретних комунікацій проекту.

Досліджено практичні аспекти визначення траєкторії розвитку життєвого циклу переваг проектів. Оцінка результатів зміни розподілу ймовірностей станів проектної системи в координатах ймовірностей станів та кроків показала істотний вплив на проекти рівня технологічної зрілості проектного середовища.

Результати дослідження можуть слугувати основою для створення моделей Форсайт-проектів, які містять відображення життєвого циклу переваг реальних проектів і враховують рівень технологічної зрілості проектного середовища.

\section{СПИСОК ЛІТЕРАТУРИ}

1. Biloshchytskyi, A., Kuchansky, A., Andrashko, Yu., Biloshchytska, S., Kuzka, O., Shabala, Ye., Lyashchenko, T. A method for the identify-cation of scientists' research areas based on a cluster analysis of scientific publications // Eastern-European Journal of Enterprise Technologies. 2017, № $5 / 2$ (89). C. $4-10$. DOI: 10.15587/1729-4061.2017.112323.

2. Drozd, J., Drozd, A. Models, methods and means as resources for sol-ving challenges in co-design and testing of computer systems and their components // International Conference on Digital Technologies. 2013. C. 176-180. DOI: 10.1109/DT.2013.6566307.

3. Durand, G., Belacel, N., La Plante, F. Graph theory based model for learning path recommendation. Information Sciences. 2013, № 251. C. 10-21. DOI: 10.1016/j.ins.2013.04.017

4. Qureshi, S.M., Kang, C. Analysing the organizational factors of project complexity using structural equation modelling. International Journal of Project Management. 2015, № 33 (1). C. 165-176. DOI: 10.1016/j.ijproman.2014.04.006.

5. Managing Successful Programmes (MSP $\AA)$ 4th Edition. 2011. 301 c. URL: https://www.itgovernance.co.uk/shop/ product/ managing-successful-programmes-2011-edition

6. Lukianov, D., Bespanskaya-Paulenka, K., Gogunskii, V., Kolesnikov, O., Moskaliuk, A., Dmitrenko, K.: Development of the markov model of a project as a system of role communications in a team. Eastern-European Journal of Enterprise Technologies. 2017, 3/3 (87). C. 21-28. DOI: 10.15587/1729-4061.2017.103231.

7. Карбони, Джоэл Б. Стандарт по обеспечению устойчивого развития в управлении проектами GPM P5тм GPM Global. Версия 2.0. 2019. 
8. Demin, D. Perfection of approaches to the construction of the training process of athletes, considered in the framework of the implementation of the processes of non-formal education // Journal «Science Rise: Pedagogical Education». 2017, № 9(17). C. 28-46. DOI: 10.15587/2519-4984.2017.111110.

9. Verkhivker, G., Kravchenko, $V$. The use of chemical recuperation of heat in a power plant // Energy. 2004, № 29(3). C. 379-388. DOI: 10.1016/j.energy.2003.10.010.

10. Developing a system for the initiation of projects using a Markov chain / В.Д. Гогунский, А.П. Бочковский, А.Ю. Москалюк, A.E. Ко-лесников, С.Н. Бабюк // Eastern-European Journal of Enterprise Technologies. 2017. № 1/3 (85). C. 25-32. DOI: 10.15587/1729-4061.2017.90971.

11. "Lifelong learning» is a new paradigm of personnel training in enterprises / V. Gogunskii, A. Kolesnikov, K. Kolesnikova, D. Lukianov // Eastern-European Journal of Enterprise Technologies. 2016. № 4/2 (82). C. 4-10. DOI: 10.15587/1729-4061. 2016. 74905.

12. Development of the model of interaction among the project, team of project and project environment in project system $/ O$. Kolesnikov, V. Gogunskii, K. Kolesnikova, D. Lukianov, T. Olekh // Eastern-European Journal of Enterprise Technologies. 2016. № 5/9(83). C. 20-26.

13. Representation of project systems using the markov chain / В.Д. Гогунський, О.С. Колесніков, Г.Г. Оборська, А.Ю. Москалюк, К.В. Колеснікова, С.В. Гарелік, Д.В. Лук'янов // EasternEuropean Journal of Enterprise Technologies. 2017. № 1/3 (85). C.25-32.

14. Chernov, S. Constructing the system of decision-making support while creating the strategy of the high-technology enterprise development [Tекст] / S. Chernov, L. Chernova // Computer Sciences and Information Technologies (CSIT), IEEE 2017. P. 7-10.

15. Bourne, L. Stakeholder Relationship Management: A Maturity Model for Organisational Implementation [Tекcm] / Lynda Bourne. Gower Publishing Limited. Farnham, UK. 2009. 215 p.

16. Chernova, L. Peculiarities of the methodologies for managing projects and proqrammes to ensure the innovation process [Tекст] / L. Chernova // Наукове періодичне видання "Системи управління, навігації та зв'язку». Полтава, 2018.Вип. 5(51). C. 121-127. 
17. Carboni, J., Young, M., Milsom, P.\& Gonzalez, M. The GPM®Global P5TM Standard for Sustainability in Project Management. Ver. 1.5. GPM Global. 2016. 43 c. URL: https:// www. greenprojectmanagement. $r g /$ the-p5-standard.

18. Rehacek, I.P. Application and usage of the standards for project management and their comparison // Journal of Engineering and Applied Sciences. 2017, № 12 (4), C. 994-1002. DOI: 10.3923/jeasci.2017.994.1002.

19. Biloshchytskyi A., Myronov O., Reznik R., Kuchansky A., Andrashko Yu., Paliy S., Biloshchytska S. A method to evaluate the scientific activity quality of HEIs based on a scientometric subjects presentation model // Eastern-European Journal of Enterprise Technologies. 2017, № 6/2 (90). C. 16-22. DOI: 10.15587/17294061.2017.118377.

\section{REFERENCES}

1. Biloshchytskyi, A., Kuchansky, A., Andrashko, Yu., Biloshchytska, S., Kuzka, O., Shabala, Ye., Lyashchenko, T. A method for the identification of scientists' research areas based on a cluster analysis of scientific publications // Eastern-European Journal of Enterprise Technologies. 2017, № 5/2 (89). C. 4-10. DOI: 10.15587/ 1729-4061. 2017.112323.

2. Drozd, J., Drozd, A. Models, methods and means as resources for sol-ving challenges in co-design and testing of computer systems and their components // International Conference on Digital Technologies. 2013. C. 176-180. DOI: 10.1109/DT.2013.6566307.

3. Durand, G., Belacel, N., La Plante, F. Graph theory based model for learning path recommendation. Information Sciences. 2013, № 251. C. 10-21. DOI: 10.1016/j.ins.2013.04.017.

4. Qureshi, S.M., Kang, C. Analysing the organizational factors of project complexity using structural equation modelling. International Journal of Project Management. 2015, № 33 (1).C. 165-176. DOI: 10. 1016/j.ijproman.2014.04.006.

5. Managing Successful Programmes (MSP®) 4th Edition. 2011. 301 c. URL: https://www.itgovernance.co.uk/shop/ product/ managing-successful-programmes-2011-edition

6. Lukianov, D., Bespanskaya-Paulenka, K., Gogunskii, V., Kolesnikov, O., Moskaliuk, A., Dmitrenko, K.. Development of the markov model of a project as a system of role communications in a team. Eastern-European Journal of Enterprise Technologies. 2017, 3/3 (87). C. 21-28. DOI: 10.15587/1729-4061.2017. 103231. 
7. Carboni Joel B. Standard for Sustainable Development in Project Management GPM P5 ${ }^{\mathrm{TM}}$ GPM Global. Version 2.0. 2019.

8. Demin, D. Perfection of approaches to the construction of the training process of athletes, considered in the framework of the implementation of the processes of non-formal education // Journal «ScienceRise: Pedagogical Education». 2017, №9(17). C. 28-46. DOI: $10.15587 / 2519-4984.2017 .111110$.

9. Verkhivker, G., Kravchenko, $V$. The use of chemical recuperation of heat in a power plant // Energy. 2004, № 29(3). C. 379-388. DOI: 10.1016/j.energy.2003.10.010.

10. Developing a system for the initiation of projects using a Markov chain / Viktor Gogunskii, Andrew Bochkovskii, Andrii Moskaliuk, Olexii Kolesnikov, Serhii Babiuk // Eastern-European Journal of Enterprise Technologies. 2017. № 1/3 (85). C. 25-32. DOI: 10.15587/1729-4061.2017.90971.

11. "Lifelong learning» is a new paradigm of personnel training in enterprises / V. Gogunskii, A. Kolesnikov, K. Kolesnikova, D. Lukianov // Eastern-European Journal of Enterprise Technologies. 2016. № 4/2 (82). C. 4-10. DOI: 10.15587/17294061.2016.74905.

12. Development of the model of interaction among the project, team of project and project environment in project system / O. Kolesnikov, V. Gogunskii, K. Kolesnikova, D. Lukianov, T. Olekh // Eastern-European Journal of Enterprise Technologies. 2016. № 5/9(83). C. 20-26.

13. Representation of project systems using the markov chain / $V$. Gogunskii, O. Kolesnikov, G. Oborska, A. Moskaliuk, K. Kolesnikova, S. Harelik, D. Lukianov // Eastern-European Journal of Enterprise Technologies. 2017. № 2/3 (86). C.60-65.

14. Chernov, S. Constructing the system of decision-making support while creating the strategy of the high-technology enterprise development [Text] / S. Chernov, L. Chernova // Computer Sciences and Information Technologies (CSIT), IEEE 2017. P. 710.

15. Bourne, L. Stakeholder Relationship Management: A Maturity Model for Organisational Implementation [Text] / Lynda Bourne. Gower Publishing Limited. Farnham, UK. 2009. 215 p.

16. Chernova, L. Peculiarities of the methodologies for managing projects and proqrammes to ensure the innovation process [Text] / L. Chernova // The scientific periodical "Systems of control, navigation and communication» Vol.5 (51). Poltava, 2018. P.121127. 
17. Carboni, J., Young, M., Milsom, P.\& Gonzalez, M. The GPM® Global P5TM Standard for Sustainability in Project Management. Ver. 1.5. GPM Global. 2016. 43 c. URL: https://www. greenprojectmanage- ment.org/the-p5-standard.

18. Rehacek, I.P. Application and usage of the standards for project management and their comparison // Journal of Engineering and Applied Sciences. 2017, № 12 (4). C. 994-1002. DOI: 10.3923/ jeasci. 2017.994.1002.

19. Biloshchytskyi A., Myronov O., Reznik R., Kuchansky A., Andrashko Yu., Paliy S., Biloshchytska S. A method to evaluate the scientific activity quality of HEIs based on a scientometric subjects presentation model // Eastern-European Journal of Enterprise Technologies. 2017, № 6/2 (90). C. 16-22. DOI: 10.15587/17294061.2017.118377.

Стаття надійшла до редакиії 